\title{
Farewell to the University (without Nostalgia); or, Thoughts on the Relation between the University and the Common ${ }^{1}$
}

\author{
CESARE CASARINO \\ Professor and Chair of Cultural Studies and Comparative Literature, \\ University of Minnesota
}

Sign of the times...or failure of the imagination...or both. Similar versions of this short essay were presented as a paper - first in 2010 at a conference titled 'Beneath the University, the Commons', organised by graduate students, union activists and artists, and held at the West Bank Social Center in Minneapolis, USA, and secondly in 2015, at a webinar organised by The New Centre for Research \& Practice. The fact that the venues were not universities or other traditional academic institutions such as research institutes or policy think tanks already points in the direction of the main arguments of this essay. Here, however, I mention the previous iterations of this short essay simply because I find it unfortunate that its arguments are still relevant after seven years: I had hoped, against my own presentiments, that some of the processes described therein - the corporatisation of the university in its various forms in primis - would have reversed or at least slowed down, but they have only accelerated and intensified. I had hoped also that different and better solutions to the problems indicated here would have emerged into view, but I see none now that differs significantly from the possibly unrealistic and certainly debatable ones I had sketched back then.

Before articulating my arguments, however, a clarification of terminology is in order. All that follows presumes a distinction between two undoubtedly interrelated concepts, namely, the commons and the common: by the former, I intend roughly what is typically referred to as 'natural resources' (e.g. water, oil), that is, forms of being that are regulated by a law of depletion and an economy of scarcity; by the latter, I intend that which human beings share in common qua human forms of being, which hence constitutes the basis of any type of communication among them, which hence always constitutes social relations, and which is regulated by a law of surplus and an economy of excess, namely, thought, language, affect in their myriad forms. In my work, I take it as axiomatic that there is no such thing as a solitary thought, as an individual language, or as a personal affect, even though, from a phenomenological standpoint, we may experience them as that which is most personal and unique about ourselves. In short, I take it as axiomatic that thought, language and affect constitute the common. Further, it is important to note also that thought, language, affect

1 I am very grateful to Jason Adams, Morgan Adamson, Christopher Breu, Micah Sapp, Ross Truscott, Maurits van Bever Donker, as well as two anonymous readers for insightful comments on earlier versions of this essay. 
all converge in knowledge (and that the university in modernity has been a privileged site for the production and circulation of knowledge). ${ }^{2}$

Having posited such a distinction between the common and the commons, let me dismantle it, or at least problematise it, right away. Indeed, there are several different ways of problematising this distinction, and many scholars have undertaken this task. ${ }^{3}$ Here, I would like simply to point out that this distinction cannot be made in terms that would, on the one hand, align the common with the human, the histori$\mathrm{cal}$, and the cultural, and, on the other, align the commons with the natural. In other words, not only are we not here in the presence of a Nature/Culture opposition but also both the common and the commons are to be understood at once as fully cultural and fully natural. This is so for various reasons. First, with respect to the commons, there is nothing natural as opposed to human or historical or cultural about so-called 'natural resources', to the extent to which a 'resource' is the name given by humans to a form of being that is a 'resource' for us humans and that, hence, is drawn, willy-nilly, into the symbolic and material processes of human production and reproduction. Put differently, any form of being (including, obviously, a human being) that is called and used as a 'resource' is turned actively into a 'resource' always for and within a specific historical mode of production (the history of the fossil fuels industry is a perfect case in point). Secondly, with respect to the common, there is nothing cultural and historical as opposed to natural about it, to the extent to which human beings - and hence also their culture and their history - are part and parcel of the natural in the first place. In this respect, I think in the wake of that (largely heretical and marginalised) current of thought in modernity which started with Baruch Spinoza and which conceives of the relation between human beings and nature precisely as not one of imperium in imperio - that is, not as a relation of a state within a state - and which, on the contrary, understands human culture and history as a constitutive and constituted subset of nature and as abiding by laws that regulate all forms of being, human or not, which forms of being, crucially, never cease to have their specificities and singularity for abiding by such common laws. ${ }^{4}$ Thirdly, and most importantly for

2 I have elaborated such a conception of the common primarily in 'Surplus Common' (my single-authored preface to a book I co-authored with Antonio Negri, In Praise of the Common), as well as in my essay 'Universalism of the Common'. See Casarino Cesare and Antonio Negri, In Praise of the Common: A Conversation on Philosophy and Politics (Minneapolis, MN: University of Minnesota Press, 2008), 1-39; Casarino Cesare, 'Universalism of the Common', Diacritics, 39(4) (Winter 2009), 162-176. The literature on the question of the common is copious. I have benefited from much of it, and refer to some of it later in this essay. Here, I would like to acknowledge that, in thinking about the common, I have found Negri's work as well as Michael Hardt and Negri's work, especially Multitude: War and Democracy in the Age of Empire (New York: Penguin, 2004) and Commonwealth (Cambridge, MA: Harvard University Press, 2009), to be particularly useful. Most importantly, my understanding of the common is shaped by the thought of Karl Marx and Baruch Spinoza.

3 The vast literatures on the question of the Anthropocene (including the various critiques of these literatures) have done much to problematise this distinction. For my purposes, I find the problematisations conducted at the intersection between the philosophical discourses of biopolitics and the Marxian critique of political economy to be the most productive. See, among others, Melinda Cooper's work and especially her Life as Surplus: Biotechnology and Capitalism in the Neoliberal Era (Seattle, WA: University of Washington Press, 2008).

4 For Spinoza's famous invocation of the locution imperium in imperio when describing the relation between human beings and nature, see, among other places in his work, the Preface to Part Three of his Ethics, edited and translated by G.H.R. Parkinson (Oxford: Oxford University Press, 2000), 163. In terms of the laws by which all forms of being - or, in Spinoza's terminology, all modes of substance - abide, first and foremost among these is what he refers to as conatus, namely, the striving to persevere in being, which, on the one hand, all forms of being have, and, on the other hand, is singular in each and every form of being. On this matter, see my 'Grammars of Conatus; or, On the Primacy of Resistance in Spinoza, Foucault, and Deleuze' in Kiarina Kordela and Dimitris Vardoulakis, eds., Spinoza’s Authority, Volume 1 (London: Bloomsbury Publishing, 2017), 57-85. 
the arguments of this essay, we are currently witnessing a rampant privatisation of both the commons and the common in all of their forms at the hands of globalising capital worldwide. In short, the distinction between the common and the commons is invoked here no more yet no less as a theoretical-methodological heuristic device.

It is specifically the common, nonetheless, that concerns me in this essay - and especially its relation to the university. Michael Hardt and Antonio Negri end two of their works - Commonwealth and Declaration - with impassioned calls to build new institutions, that is, institutions of the common. ${ }^{5}$ The question I would like to begin formulating here is: 'Can the university be an institution of the common?' But there is perhaps another question that needs to be addressed first: 'Do we want the university at all?' This is not a rhetorical question. Let me ask it again: in the present historical conjuncture, and, in particular, in the face of the current and ongoing corporatisation of the public university, is it worth continuing to employ our labour, time, thought and effort in attempting to transform this institution radically? Or are our efforts, struggles and lives better spent and valorised instead by incepting a mass exodus from the corporatising university and by working towards imagining and building different types of institutions altogether (along with their attendant and constitutive forms of subjectivity and sociality)?

Others have already analysed and critiqued in detail the various processes of corporatisation of the public university, and hence I will not repeat those familiar accounts. ${ }^{6}$ I limit myself to pointing out that this corporatisation needs to be understood as part of a larger process of privatisation of the common in all of its forms, and as part, in particular, of that systematic demolition of any remaining institution of what used to be called the welfare state (intended here in its widest, loosest sense), which demolition is concomitant with and integral to such a privatisation of the common. With the shift from the public university to the corporatising university, the educational vocations and ideological functions of the welfare state are thus directly transferred to and managed by globalising capitalism. In short, this is a shift from

Hardt and Negri, Commonwealth, 355-359, but see also 376-383. Michael Hardt and Antonio Negri, Declaration (New York: Argo-Navis Author Services, 2012), 49-99. On the question of the institutions of the common, as well as for a distinction between the common and the commons that is at once alternative and related to the one I articulate at the beginning of this essay, see also Gigi Roggero, 'Five Theses on the Common', Rethinking Marxism, 22(3) (2010), 357-373.

6 One of the first and still highly relevant studies on the transformation of the university is Bill Readings' The University in Ruins (Cambridge, MA: Harvard University Press, 1996). More recently, a spate of new books has appeared on this topic. Among others, see Christopher Newfield, Unmaking the Public University: The Forty-Year Assault on the Middle Class (Cambridge, MA: Harvard University Press, 2008) and The Great Mistake: How We Wrecked Public Universities and How We Can Fix Them (Baltimore, MD: Johns Hopkins University Press, 2016); Marc Bousquet, How the University Works: Higher Education and the Low-Wage Nation (New York: New York University Press, 2008); and Stefan Collini, What Are Universities for? (New York: Penguin Press, 2012). But see also numerous essays and articles such as Noam Chomsky, 'The Death of American Universities', Jacobin, https://www.jacobinmag.com/2014/03/the-death-of-american-universities/ (accessed September 2017) and Jeffrey J. Williams, 'The Post-Welfare State University', American Literary History, 18(1) (2006), 190-216, as well as those edited by Luka Arsenjuk and Michelle Koerner for the Polygraph, 21 (2009) special issue 'Study, Students, and Universities'. Importantly, this special issue of Polygraph included a round-table discussion with Marc Bousquet, Stefano Harney and Fred Moten, which provided some of the bases for Harney and Moten's further elaborations in their book The Undercommons: Fugitive Planning \& Black Study (Chico, CA: AK Press, 2013), which also engages with the question of the university and to which I return briefly (see notes 8 and 9). For analyses of how the transformation of the university has affected women as well as racial, sexual and other minorities, see Sara Ahmed, On Being Included: Racism and Diversity in Institutional Life (Durham, NC: Duke University Press, 2012); Roderick A. Ferguson, The Reorder of Things: The University and Its Pedagogies of Minority Difference (Minneapolis, MN: University of Minnesota Press, 2012); as well as the collection of essays edited by Michelle A. Massé and Katie J. Hogan, Over Ten Million Served: Gendered Service in Language and Literature Workplaces (Albany, NY: SUNY Press, 2010). 
what Louis Althusser called 'ideological state apparatus' in 1969 to what now might be called ideological capitalist apparatus. ${ }^{7}$ The shift from the public university to the corporatising university, in any case, is one of the latest symptoms of the destruction of the welfare state and of the privatisation of the common.

The management of the common under the aegis of the welfare state, however, was notoriously far from ideal. The story of how the Keynesian model underpinning the welfare state turned into an extremely effective instrument of political cooptation is well known. I am suggesting, in other words, that the public university of yore - all its undoubted merits and virtues notwithstanding - constituted already a rather limited and limiting form of the common precisely to the extent to which it was a crucial institution of the welfare state. Some might argue, though, that the public university as we knew it up until not too long ago was also the product of the student struggles of the 1960s and 1970s, and especially of the urgent demand for student representation and student participation in the decision-making processes of all aspects and at all levels of university life. But it is these demands for representation and participation that the institutions of the welfare state in the end were always able to accommodate precisely because the welfare state had been created so as to neutralise and co-opt such demands in the first place. Put differently, the public university was precisely that - public rather than common (where the common needs to be understood also as that which enables and yet is concealed by the distinction between public and private, as the foreclosed ground of the entire public/private dialectical binary, which is, of course, a foundational binary of capitalist ideology). Just because the corporatising university may well be worse from the standpoint of the expression and institution of the common than the public university ever was, it does not follow that we should feel any nostalgia for the public university. Should we defend the public university from its corporate takeover? Should we fight for the public university? If and when our common survival as students and teachers is at stake in it, by all means, yes, let us defend and fight for it. Let us do so, however, without either nostalgia or illusions. Let us do so, above all, keeping in mind that a struggle for survival and a revolutionary struggle are not necessarily one and the same thing: just because at a certain moment in history it becomes necessary for us to do something in order to survive, it does not mean that that something constitutes a revolutionary act. Put differently, to defend and make demands in the name of the public university nowadays may well be at once necessary for our survival as well as a specifically defensive and necessarily conservative political act. We cannot afford merely to defend ourselves not the least reason being that there is no weaker defence than that defence which does not constitute simultaneously a counterattack.

This is why, while I recognise the strategic necessity to defend this or that specific aspect of the public university, I also wonder what a mass exodus from the university might look like and yield. By 'mass exodus from the university' I do not mean

7 Louis Althusser, 'Ideology and Ideological State Apparatus (Notes towards an Investigation)' in Lenin and Philosophy and Other Essays, translated by Ben Brewster (New York: Monthly Review Press, 2001), 127-187. 
necessarily that people suddenly should stop attending colleges and universities, stop seeking employment in such institutions, or quit their current jobs there - though it might be a productive political thought-experiment to imagine a scenario in which, for example, students would defect from the university in droves, and would-be students would never enter the university in the first place, either because they realised that they are, as it were, getting increasingly less and paying increasingly more for it, thereby joining the ranks of those who are burdened by student debt for life, or for a host of other reasons. More precisely, by 'mass exodus from the university' I mean a systematic redirection of resources of all sorts, ranging from financial to psychological, from intellectual to infrastructural, and beyond. As I increasingly lose hope in the radical potentials of the university as an institution, I believe that, rather than funnelling the various university resources which are available to us and which include us back into the reproduction of this institution, we ought to redirect such resources whenever possible and whenever useful into building new types of institutions outside and beyond the confines of both the past and the present university. (It is entirely accurate, as well as acceptable to me, to characterise such a process of redirection of resources as theft, much like, for example, Stefano Harney and Fred Moten do in their remarkable and compelling book The Undercommons - as long as one agrees that in this context theft constitutes nothing other than taking back and reclaiming bits and pieces of the common that have been privatised). ${ }^{8}$ I envisage such new institutions as institutions for the production and circulation of common knowledge as well as of knowledge of the common. Neither public nor private, the coming university might be one day the common university. ${ }^{9}$

I find, for example, Harney and Moten's pithy formulation - 'the only possible relationship to the university today is a criminal one' - to be not only defensible but also entirely warranted, as long as it is clear that what is truly 'criminal' (that is, not legally but ethically untenable) is the legal thought and its appertaining juridical forms and judicial institutions that define the reclaiming of the common as 'theft' and hence as a punishable crime in the first place. Undoubtedly, this is one of the reasons why in the Italy in which I grew up this type of 'theft' was rebaptised by many on the extra-parliamentary left as esproprio proletario, a locution which translates into English as 'proletarian expropriation', which was in part inspired by and readapted from Latin American revolutionary movements of the 1960s and 1970s (e.g. Tupamaros), and which - even though it is no longer possible for me to utter it with the utterly unironic seriousness and self-important fervour of my adolescent self - is still nonetheless useful in reminding us that reclaiming the common can be understood and defined as stealing only from the standpoint of the public/ private dialectic. There is no theft in taking back what was always already one's own. See Harney and Moten, The Undercommons, 26 , but also $26-30$.

9 Since I have already invoked Harney and Moten's The Undercommons, let me clarify what may seem to constitute a significant difference between some of my arguments and theirs, which difference, however, may turn out to be more of a terminological divergence than a conceptual disagreement in the end. Put briefly, whereas I assert the need to build institutions of the common, and whereas I understand the fulfilment of this need as an urgent political task, they seem to disavow institutions as well as politics altogether. At one point, for example, they write: 'In the clear, critical light of day, illusory administrators whisper of our need for institutions, and all institutions are political, and all politics is correctional, so it seems we need correctional institutions in the common, settling it, correcting us. But we won't stand corrected. Moreover, incorrect as we are there's nothing wrong with us. We don't want to be correct and we won't be corrected. Politics proposes to make us better, but we were good already in the mutual debt that can never be made good. We owe it to each other to falsify the institution, to make politics incorrect, to give the lie to our own determination. We owe each other the indeterminate. We owe each other everything...An abdication of political responsibility? OK. Whatever. We're just anti-politically romantic about actually existing social life. We aren't responsible for politics. We are the general antagonism to politics looming outside every attempt to politicize, every imposition of selfgovernance, every sovereign decision and its degraded miniature, every emergent state and home sweet home... [W] got politics surrounded. We cannot represent ourselves. We can't be represented' (p. 20). There is much to agree with - and, I daresay, to love - in this and other beautiful and passionate passages of this book: for example, we do indeed 'owe each other everything' (and, I might add, capitalist exchange relations have turned this incalculable, immeasurable and unrepayable mutual debt - which constitutes the very fabric of the social by producing pacts, bonds and, in short, human cooperation - into the current tyranny of calculable, measurable and repayable debt that suffocates whatever remains of the social everywhere); 'there's' indeed 'nothing wrong with us' and 'we won't be corrected', even though, or precisely because, we are 'incorrect'; in fact, we cannot even 'represent ourselves' or 'be represented' - and that is a good thing too; we should most certainly be suspicious of administrators and their whispers (including these very words I am writing here, given that I currently occupy a low-level management position in the 
It seems to me that this political project of exodus is well under way. The venues at which I first delivered earlier versions of this essay are concrete examples of it. Other experiments - largely non-degree-granting organisations that don't seek accreditation and that may or may not have some degree of connection with one or more traditional academic institutions - have been emerging and interacting with one another worldwide for at least the last decade: one thinks here, among many others, of The New Center for Research \& Practice with its online seminars (based in Grand Rapids, USA); of Ars Industrialis (founded by Bernard Stiegler in Paris, France); of the Allegra Lab collective (registered in Finland) and of its various projects aimed at providing alternatives to current academic publishing; of the Edu-factory collective and its proposal for a global autonomous university; of the Vidya Ashram collective and its theory and practice of lokavidya in Varanasi and other locations in India; of the London-based University for Strategic Optimism - a short-lived yet intense and diverse set of academic experimentations born out of the struggles and demonstrations against government cuts to education in 2010 in the UK; of EXCO (Experimental Community Education) and its free course offerings in Minneapolis and St. Paul, USA; of the (now defunct) UniNomade itinerant seminars across the

academic corporation as department chair at a university); we do, indeed, trust in 'actually existing social life' - and so on. Butand this is where the terminological, if not necessarily conceptual, divergences begin - 'actually existing social life' is and cannot be anything other than politics. It is so, at least, for me. (It hence follows that for me, politics is also not 'correctional.) Put differently, the 'politics' that is disavowed in this and other passages of The Undercommons is representational politics that has foreclosed its relation to the ontological: this, from my standpoint, makes such 'politics' at best only very limitedly political, and hence makes Harney and Moten's disavowal of it perfectly legible and understandable. But why call this politics at all? Why call all politics this in the first place? Why insist on calling this politics simply because that is the dominant definition and practice of politics today? (And isn't this akin to calling theft what in fact is not theft at all? On this matter, see the previous note.) Perhaps the answer to these questions lies ultimately in the historical bankruptcy of certain terms and, inevitably, of their appertaining concepts. It may well be the case that the myriad ways in which the term 'politics' has been defined, practised, used and abused throughout its long and complicated history, including and especially in our present historical conjuncture, makes this term so tainted as to be altogether unusable for Harney and Moten's projects. (Indeed, I feel similarly, for example, about the term 'democracy': even though I recognise that there exist highly commendable, undoubtedly productive, truly valiant attempts to recuperate and re-elaborate the term 'democracy' by excavating and retracing, for example, the too often unsung, unacknowledged, underground genealogies of the radical democratic project - attempts such as one finds, among others, in some of Hardt and Negri's work - I still cannot bring myself to use the term 'democracy' in any positive sense because the last 250 years [namely, the history of the rise, decline and fall of representative, liberal democracies] have ruined it for me, that is, because its dominant history has made this term so compromised that I am unable to put it to good use politically or otherwise, which inability, no doubt, may well be my own limitation, yet another failure of the imagination...) The point is that I would prefer not to give up on (the term) 'politics', which I believe can be rendered and reduced to the level of the representational only through cynical impoverishments and disastrous distortions, and which I believe always to be intimately linked, willy-nilly, to the level of the ontological (and it would take me farther afield to explain precisely why and how Gilles Deleuze and Félix Guattari's dictum 'avant l'Être, il y a la politique'/'before Being, there is politics' - provides the compass of any investigation into the political I might care to undertake). Likewise, as soon as one speaks of 'actually existing social life', one speaks not only of politics but also of rules and regulations and, hence, of institutions. Even though the term 'institution' may bring to mind a great variety of forms of organisation that are oppressive and exploitative of the common - ranging from the patriarchal family to the International Monetary Fund, from the carceral system to ExxonMobil - it seems to me that to jettison this term simply because of many of its actually existing materialisations constitutes the proverbial throwing away of the baby with the bathwater. Let us not lose sight of the fact that, at its barest, an institution is also something involving an actual (e.g. brick and mortar) and/or virtual (e.g. electronic) space of assembly where human and other beings may come together to pursue common projects, where a collectivity may form in and by the process of giving itself immanent rules and regulations as opposed to being formed by and hence having to adopt and adapt to a priori and transcendent laws (where the difference between such rules and such laws is that the former, unlike the latter, do not exist outside and prior to the social game being played and hence have to emerge from the game itself and have to be made up as one goes along, non-teleologically and experimentally: once upon a time, Karl Marx and Friedrich Engels, followed by Leon Trotsky, used to call this process permanent revolution). If, as Deleuze and Guattari show, a deterritorialisation always entails and constitutes also a reterritorialisation, I believe institutions to be, for better and for worse, the reterritorialising aspects of that process of ebb and flow which is politics as 'actually existing social life'. I also believe that the relation between fugitivity and refuge in Harney and Moten's work is akin to the relation between deterritorialisation and reterritorialisation - and that what I am calling institutions of the common constitute the (always temporary, always provisional, always fragile) refuge of the fugitive. For Deleuze and Guattari's understanding of deterritorialisation and reterritorialisation as always imbricated, see at the very least A Thousand Plateaus: Capitalism and Schizophrenia, translated by Brian Massumi (Minneapolis, MN: University of Minnesota Press, 1987), 10 and 508-510. 
Italian peninsula; of the Noötechnics collective, with its online as well as offline conferences and debates that bring together independent scholars and academics from Denmark, France, Italy, the UK and the USA; of Libera Università Metropolitana (Free Metropolitan University) associated with the Esc Atelier social centre in Rome, Italy; of the Laboratory of Insurrectionary Imagination, which pointedly refuses to define itself as 'an institution or a group', or a 'network' or an 'NGO', which defines itself instead as 'an affinity of friends who recognise the beauty of collective creative disobedience, ${ }^{10}$ and which has been active primarily in the European Union, mixing political protest with performance art, video art, philosophical reflection and theatre; and last but not least, of the Factory for the Arts, associated with the Centre for Humanities Research of the University of the Western Cape (UWC), in Cape Town, South Africa. We need many more such experiments and, conversely, such experiments need our energies more than ever.

Ultimately, I am proposing a lopsided, double-pronged strategy: we need to work and struggle at once within and against the university as well as outside and beyond the university. Moreover, we need to put much more emphasis on the outside and beyond rather than on the within and against. The common university does not exist yet in actuality - but I do sense its powerful potentials in these current, ongoing, actual struggles.

Having said all that, let me end on a somewhat different note (which has been suggested to me in part by an ongoing collaborative project with Maurits van Bever Donker, involving, among other things, co-developing and then co-teaching a seminar titled 'Global Apartheid: A Genealogy of Biopolitical Sovereignty' at the University of Minnesota as well as at UWC's Centre for Humanities Research). All of the above - including the 'lopsided, double-pronged strategy' - was written keeping in mind the corporatisation of academic institutions and public universities, specifically in the USA (though similar and related processes have been well under way within the academic systems of other countries, ranging from Canada to the UK, from France to Italy, and beyond). The uniqueness of the post-1994 South African context may well call for a somewhat different analysis as well as for tactical modifications of the aforementioned strategy. In the wake of apartheid education, after all, the political significance of struggling within and against formerly segregated public universities should not be underestimated. Such struggles in effect constitute the seizing and reclaiming of a common by those who at once had always already produced it yet were legally banned from enjoying any of its benefits. Undoubtedly, desegregation needs also to constitute a struggle outside and beyond the university - and it already does. ${ }^{11}$ Lest the 'lopsided, double-pronged strategy' ossify into a prescriptive and teleological political project like so many others, however, its relevance to this and

10 See http://www.labofii.net/about/ (accessed 28 September 2017).

11 For example, all other considerations aside, including those regarding their political effectivity, the FeesMustFall student movements constitute struggles of desegregation that have been articulated within, against, outside, beyond and even before the university all at once. 
to any other historical conjuncture ought never to be taken for granted in advance. After all, it is in affirming rather than foreclosing the ineludible and terrifying element of the aleatory - as well as in grappling with all the real risks such an affirmation entails - that the politics of the common singularly distinguishes itself from the politics of corporate business as usual. 
